Research Article

\title{
Reduction of Offensive Odor from Natural Rubber Using Zinc-Modified Bentonite
}

\author{
Bryan B. Pajarito (D), Kayla C. Castañeda, Sofia Denise M. Jeresano, \\ and Dominique Ann N. Repoquit
}

\begin{abstract}
Polymer Research Laboratory, Department of Chemical Engineering, University of the Philippines, Diliman, Quezon City 1101, Philippines
\end{abstract}

Correspondence should be addressed to Bryan B. Pajarito; bryan.pajarito@gmail.com

Received 26 February 2018; Revised 12 June 2018; Accepted 20 June 2018; Published 16 July 2018

Academic Editor: Peter Majewski

Copyright (C) 2018 Bryan B. Pajarito et al. This is an open access article distributed under the Creative Commons Attribution License, which permits unrestricted use, distribution, and reproduction in any medium, provided the original work is properly cited.

\begin{abstract}
Natural bentonite was modified with zinc ions and was used as a filler to reduce the offensive odor from raw natural rubber (NR). Characterization of filler shows the limited exchange of inherent calcium ions and the preferred adsorption of zinc ions on the surface of natural bentonite during modification. The modification process was also accompanied by bassanite formation due to sulfate ions brought by the zinc salt. Zinc-modified bentonite demonstrates an antimicrobial effect against microorganisms that are known to degrade or produce offensive odor from raw NR. Due to its antimicrobial and adsorption properties, zinc-modified bentonite significantly reduces the offensive odor from raw NR at loadings of $2.5-7.5 \mathrm{phr}$ as shown by the olfactometry test. In terms of vulcanization characteristics, the loading of zinc-modified bentonite at $7.5 \mathrm{phr}$ caused a slight decrease in elastic torque and increase in scorch and curing times of NR. The hardness and tensile properties of vulcanized NR are maintained after compounding with zinc-modified bentonite at $7.5 \mathrm{phr}$.
\end{abstract}

\section{Introduction}

The offensive odor from raw natural rubber (NR) has been a long-standing problem of manufacturers [1]. The obnoxious odor released during processing and mastication of $\mathrm{NR}$ is undesirable to workers and a nuisance to the public residing near rubber manufacturing facilities [2, 3]. The volatile compounds produced during microbial degradation of carbohydrates, proteins, and other nonrubber components of NR generate the offensive odor [2-5]. Currently, water scrubbers are used to control the offensive odor from NR $[1,5,6]$, but the expense of installation and maintenance makes it unattractive to rubber manufacturers. Several methods based on the application of solid adsorbents and antimicrobial agents to reduce the offensive smell from raw and vulcanized NR were previously studied. Hoven et al. [1] showed the effectiveness of zeolite, chitosan, and carbon black as solid adsorbents in lowering the offensive odor from vulcanized NR. Perng et al. [7] utilized a column of granulated activated carbon to adsorb residual ozone and volatile organic compounds from an ozonation reactor which treated the odorous gas from rubber processing. Nornanysya et al. [2] soaked coagulated NR latex in dilute aqueous solutions of antimicrobial agents (sodium hypochlorite and formaldehyde) and undiluted HISKA (a coagulant and density enhancer for NR latex) to decrease the unpleasant smell. In these methods, adsorption by solid adsorbents was used to capture and limit the emission of odorous compounds, while the antimicrobial characteristics of selected liquid chemicals were employed to inhibit the microbial growth and degradation of NR.

In this study, natural bentonite was utilized as a carrier of zinc ions which are known to possess antimicrobial properties [8-11]. As a clay mineral, bentonite is also commonly used as an adsorbent [12]. Solid adsorbents such as montmorillonite (which is the main component of natural bentonite) and zeolite were previously employed as carriers or supports of heavy metal ions of silver, copper, and zinc 
[13-19]. Silver is the preferred antimicrobial agent, but its relatively high cost prompts researchers to explore the oligodynamic effect of other heavy metals such as copper and zinc. Copper seems to be a feasible choice for antimicrobial application in NR, but previous research [20] showed the susceptibility of vulcanized NR to auto-oxidation and degradation when in contact with copper ions. Therefore, this study focused on the modification of natural bentonite with zinc ions and its capability to reduce the offensive odor from raw NR.

Appropriate techniques were used to characterize the phase and elemental composition, chemical structure, and surface morphology of natural and zinc-modified bentonite in order to understand the modification process. Antimicrobial analyses were also performed on selected microorganisms to measure the antimicrobial properties of natural and zinc-modified bentonite. The reduction of offensive odor from NR using zinc-modified bentonite was investigated using an olfactometry method. After determining the optimum loading in NR for odor reduction, the effect of zinc-modified bentonite on curing and mechanical properties of NR composite was also studied and discussed.

\section{Materials and Methods}

2.1. Materials. Natural bentonite powder (industrial grade, Saile Industries Inc.) was used as received. The cation exchange capacity of natural bentonite is $134.66 \mathrm{meq}$ per $100 \mathrm{~g}$ according to the datasheet provided by the supplier. Zinc sulfate heptahydrate $\left(\mathrm{ZnSO}_{4} \cdot 7 \mathrm{H}_{2} \mathrm{O}\right.$; analytical grade, Loba Chemie Pvt. Ltd.) and deionized water were used to prepare the zinc solution. Standard Philippine rubber (SPR 10, from Rhodeco Processing Services Inc. and MJ Rubber Agricultural Products Inc.) was used for the olfactometry test and preparation of vulcanized NR samples. Compounding ingredients added to NR for vulcanization such as stearic acid, zinc oxide, sulfur, and $N$-tert-butyl-2-benzothiazyl sulfonamide (Rhodeco Processing Services Inc.) were also used as received.

The antimicrobial analysis and the required microorganisms/ materials such as M. luteus (BIOTECH 1793), X. oryzae (BIOTECH 1792), sterile saline, agar plates, $10 \%$ phenol solution, and distilled water were provided by the National Institute of Molecular Biology and Biotechnology (Laguna, Philippines).

2.2. Zinc Modification of Bentonite. Natural bentonite powder was first sieved (400 mesh, Taylor) before treatment with $0.2 \mathrm{M}$ zinc solution $\left(58 \mathrm{~g} \mathrm{ZnSO} \cdot 7 \mathrm{H}_{2} \mathrm{O}\right.$ in $1000 \mathrm{ml}$ deionized water). Constant stirring of $150 \mathrm{~g}$ natural bentonite in zinc solution was performed at room temperature for $24 \mathrm{~h}$ using a magnetic stirrer (MSH-30A, Wisd Laboratory Instruments) at $1500 \mathrm{rpm}$. The clay slurry was centrifuged (Rotofix 32A, Hettich), and the collected solid was dried in a laboratory hot air oven (DSO-500D, Digisystem Laboratory Instruments) at $90^{\circ} \mathrm{C}$ for $100 \mathrm{~h}$. Zincmodified bentonite was ground with mortar and pestle and then sieved before characterization and further tests.
2.3. Characterization of Natural and Zinc-Modified Bentonite. Phase composition of natural bentonite before and after zinc modification was obtained using a portable $\mathrm{X}$-ray diffraction machine (Terra, Olympus). The instrument used coradiation $(\lambda=1.79 \AA)$ while recording intensity data from $2 \theta=5-55^{\circ}$ with the increment of $0.05^{\circ}$. Basal spacing at specific $2 \theta$ was computed using Bragg's law. Elemental composition was measured by X-ray fluorescence analysis (XRF; BTX II, Olympus) with a resolution of $200 \mathrm{eV}$ at the $5.9 \mathrm{keV}$ peak of cobalt and an energy range of 3-25 keV.

Chemical structure of samples was studied using the Fourier transform infrared spectrometer (FTIR; Nicolet 6700, Thermo Scientific) coupled with a macrodiamond attenuated total reflectance (ATR) crystal plate accessory. The resolution of the spectrum was $2 \mathrm{~cm}^{-1}$, and the number of coadded scans was 32 . Background spectra were obtained without samples prior to actual measurement of samples.

Morphological features of samples were examined using a scanning electron microscope (SEM; S-3400N, Hitachi) operated at $5 \mathrm{kV}$ and $1000 \mathrm{x}$ magnification.

2.4. Antimicrobial Analyses. Cylinder-plate assays were performed for antimicrobial analysis of natural and zincmodified bentonite against selected microorganisms known to degrade or produce offensive odor from raw NR. Micrococcus luteus is a Gram-positive microorganism previously classified by Nornanysya et al. [3] to produce foul smell from coagulated NR latex. Xanthomonas oryzae is a Gram-negative microorganism known to degrade NR [21]. Natural or zinc-modified bentonite sample was diluted in deionized water to produce $2 \mathrm{ml}$ solution of $0.1 \mathrm{~g} \cdot \mathrm{ml}^{-1}$. The test microorganism (M. luteus or X. oryzae) from a freshly grown culture was suspended in $3 \mathrm{ml}$ sterile saline. The saline suspension was spread into the surface of an agar plate. The culture was incubated for $24 \mathrm{~h}$ at $35^{\circ} \mathrm{C}$ until growth was apparent. The inoculum was obtained from the incubated culture and added into $50 \mathrm{ml}$ sterile saline. The microorganism was then spread evenly on a new agar plate until a layer of uniform depth was formed.

Three cylinders containing $0.1 \mathrm{ml}$ of the sample solution, $10 \%$ phenol (positive control), and distilled water (negative control) were placed on the agar plate. After $18 \mathrm{~h}$, the cylinders were removed from the plate and the diameter of the inhibition zone was measured to the nearest $0.1 \mathrm{~mm}$. Mean diameter of the inhibition zone was reported using triplicate samples.

2.5. Olfactometry Test. The olfactometry method used by Hoven et al. [1] was adapted to assess the effectiveness of zinc-modified bentonite in odor reduction. Although the chromatographic analysis is usually employed to measure the concentration of volatile compounds from NR [1-3,22], Hoven et al. [1] demonstrated the capability of the technique in describing the odor reduction in NR where human testers judged and rated the odor of rubber samples. Moreover, there is no known relationship between the concentration of volatile compounds and its perceived odor [7]. To obtain statistically reliable data, 50 persons ( 25 men and 25 women) 
with ages of 18-25 years participated in the olfactometry test. References 1-5 ranging from low to high intensity of rubber odor were generated by filling 1, 5, 10, 15, and $20 \mathrm{~g}$ of raw NR in $250 \mathrm{ml}$ plastic containers, respectively. Rubber samples were prepared by masticating raw NR with natural or zincmodified bentonite $(0-10 \mathrm{phr})$ in a laboratory mixing mill (BMM-6, Bharaj Machineries Pvt. Ltd.) at room temperature. The odor of $10 \mathrm{~g}$ of the rubber sample in a $250 \mathrm{ml}$ container was compared with each reference. Each person specified the reference number that matches the odor intensity of the rubber sample. The results of the olfactometry test were reported as the percentage of people who selected each reference. The mean odor rating (minimum value $=1$; maximum value $=5$ ) was also computed for each rubber sample. Every participant had to smell the odor of coffee beans (also in $250 \mathrm{ml}$ container) before each comparison to erase their previous experience from other rubber samples and to minimize odor confusion [1].

2.6. Curing and Mechanical Tests. The raw NR sample containing zinc-modified bentonite at proportion found optimum for odor reduction was compounded with $2 \mathrm{phr}$ stearic acid, $5 \mathrm{phr}$ zinc oxide, $2.5 \mathrm{phr}$ sulfur, and $0.6 \mathrm{phr}$ $\mathrm{N}$-tert-butyl-2-benzothiazyl sulfonamide using the laboratory mixing mill. After mastication, the vulcanization parameters of the rubber sample were determined at $160^{\circ} \mathrm{C}$ using a rubber process analyzer (RPA 2000, Alpha Technologies) for $20 \mathrm{~min}$. The equipment was operated at a frequency of $100 \mathrm{cpm}$ and strain of $0.5^{\circ}$. The obtained parameters were minimum and maximum elastic torques ( $\mathrm{ML}$ and $\mathrm{MH}$ ), scorch times (time until 1 or $2 \mathrm{dNm}$ rise above ML; ts 1 and ts2), and curing times (time required for the sample to reach $50 \%$ or $90 \%$ of the total state of cure; tc50 and tc90) [23].

The NR sample compounded with curing additives was vulcanized in a compression moulding press (Chemplast, S. V. Industries) at $160^{\circ} \mathrm{C}$ and duration time indicated by it is tc90. The Shore A hardness of vulcanized sample was measured using a durometer (Kori Seiki) following ASTM D2240. The vulcanized sample was also cut into dumbbell shape (GT-7016-A, Gotech) and subjected to a tensile test using a universal testing machine (AGS-5kNX, Shimadzu) following ASTM D412. The crosshead speed used during the tensile test was $500 \mathrm{~mm} \cdot \mathrm{min}^{-1}$. Due to limited tensile stroke of the equipment and failure of vulcanized sample to break during the test, the tensile stress at 100, 200, and 300\% elongation was recorded instead of the tensile strength. Tensile set due to permanent deformation was also measured at $140 \%$ elongation following ASTM D412. The sample was strained for $10 \mathrm{~min}$ and was allowed to rest for another $10 \mathrm{~min}$ before measurement of the distance between bench marks. Five replicates were tested to report the mean hardness of the sample, while 3 replicates were used to report the mean values of tensile properties.

The Shore A hardness and tensile properties of the vulcanized sample were also obtained after air oven ageing following ASTM D573. The vulcanized sample was aged in the laboratory hot air oven at $70^{\circ} \mathrm{C}$ for $168 \mathrm{~h}$. The aged sample was then cooled at room temperature and maintained at $23^{\circ} \mathrm{C}$ for $13 \mathrm{~h}$ before testing for hardness and tensile properties.

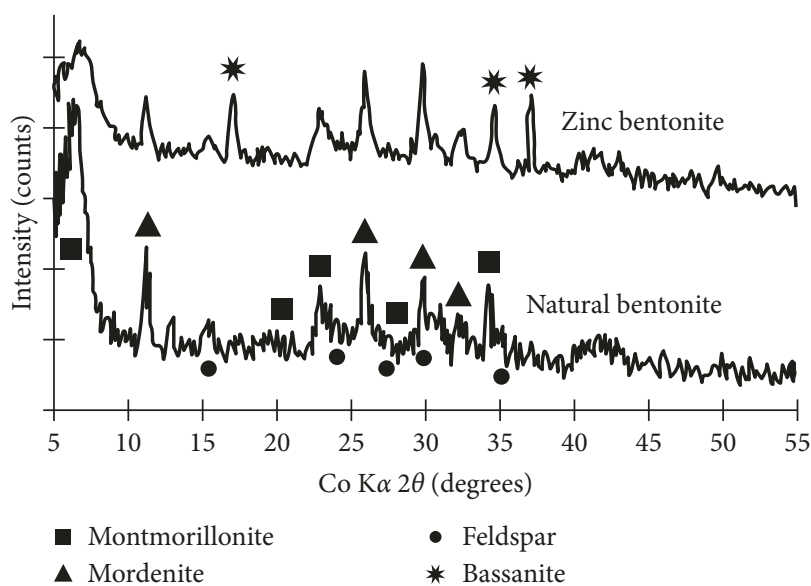

FIGURE 1: X-ray diffractogram of natural bentonite and zincmodified bentonite.

The curing characteristics and mechanical properties (before and after air oven ageing) of the vulcanized NR sample without zinc-modified bentonite were also determined and reported for comparison.

\section{Results and Discussion}

3.1. Characterization of Filler. The natural bentonite used in this study is mainly composed of montmorillonite (smectite) with traces of mordenite and feldspar (Figure 1). The previous study in Philippine natural bentonite [24] detected montmorillonite, mordenite, and hectorite. The measured composition of natural bentonite (Table 1) suggests calcium as the main exchangeable cation. The modification process lowers and broadens the reflection of montmorillonite at $2 \theta=6.35^{\circ}\left(d_{001}\right.$ basal spacing $\left.=16.15 \AA\right)$ due to the adsorption of $\left[\mathrm{Zn}\left(\mathrm{H}_{2} \mathrm{O}\right)_{6}\right]^{2+}$ complex on the surface of clay [25-27]. However, the expected shift of $d_{001}$ reflection to lower $2 \theta$ due to ion exchange and intercalation of zinc ions in the clay galleries [25-27] is not observed. The lower ionic concentration and larger size of $\mathrm{Zn}^{2+}$ than that of $\mathrm{Ca}^{2+}$ have limited the intercalation and swelling of bentonite [28].

The diffraction pattern of zinc-modified bentonite also shows the presence of bassanite $2 \mathrm{CaSO}_{4} \cdot\left(\mathrm{H}_{2} \mathrm{O}\right)$ with intense peaks at $2 \theta=17.2,34.6$, and $37.2^{\circ}$ [29]. As suggested by Wilson and Bish [30], some of $\mathrm{Ca}^{2+}$ reacted with $\mathrm{SO}_{4}{ }^{2-}$ to form bassanite. The presence of calcium (9.89 wt.\%) and sulfur (9.19wt.\%) in zinc-modified bentonite (Table 1) further indicates bassanite formation. Moreover, the high concentration of calcium and zinc (32.30 wt.\%) in modified bentonite denotes limited ion exchange of $\mathrm{Ca}^{2+}$ and preferred adsorption of $\mathrm{Zn}^{2+}$ into the clay surface.

Zinc modification also results in dealumination of bentonite [31] (Table 1) due to the weak acidity of zinc sulfate solution [32]. Zinc- and sulfur-free composition of zinc-modified bentonite shows considerable enrichment in silicon due to the dissolution of aluminum. Meanwhile, other elements such as iron and calcium are retained in bentonite after zinc modification. 
TABle 1: Composition of natural bentonite and zinc-modified bentonite by XRF analyses.

\begin{tabular}{lccc}
\hline $\begin{array}{l}\text { Analyte } \\
(\text { wt.\%) }\end{array}$ & $\begin{array}{c}\text { Natural } \\
\text { bentonite }\end{array}$ & $\begin{array}{c}\text { Zinc } \\
\text { bentonite }\end{array}$ & $\begin{array}{c}\text { Zinc bentonite (Zn- and } \\
\text { S-free) }\end{array}$ \\
\hline $\mathrm{Si}$ & 46.0 & 31.5 & 53.8 \\
$\mathrm{Fe}$ & 25.7 & 14.5 & 24.8 \\
$\mathrm{Al}$ & 8.74 & - & - \\
$\mathrm{K}$ & 1.32 & 0.81 & 1.38 \\
$\mathrm{Ti}$ & 1.42 & 0.77 & 1.32 \\
$\mathrm{Ca}$ & 15.5 & 9.89 & 16.9 \\
$\mathrm{Zn}$ & 0.05 & 32.3 & - \\
$\mathrm{Cu}$ & 0.08 & 0.07 & 0.12 \\
$\mathrm{Sr}$ & 0.24 & 0.17 & 0.29 \\
$\mathrm{Mn}$ & 0.85 & 0.48 & 0.82 \\
$\mathrm{Zr}$ & 0.08 & - & - \\
$\mathrm{V}$ & 0.06 & - & - \\
$\mathrm{S}$ & - & 9.19 & - \\
$\mathrm{Ba}$ & - & 0.36 & 0.61 \\
\hline
\end{tabular}

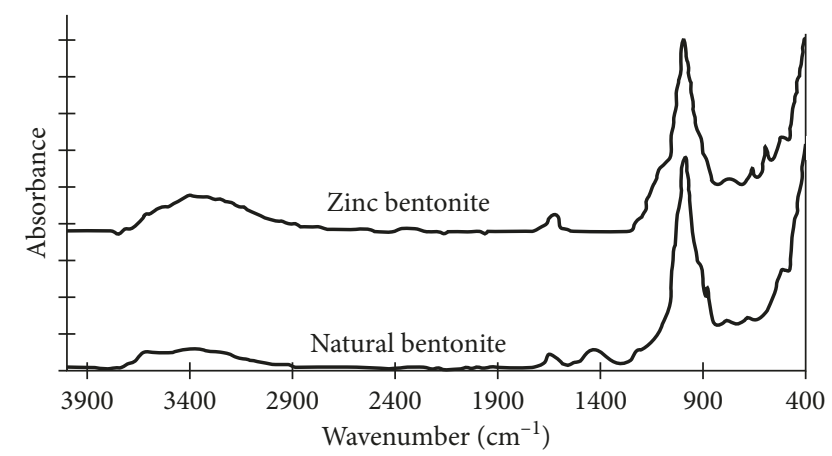

FIgURE 2: ATR-FTIR spectrum of natural bentonite and zincmodified bentonite.

The infrared bands of as-received natural bentonite (Figure 2) show $\mathrm{OH}$ stretching and deformation of water (3390 and $\left.1630 \mathrm{~cm}^{-1}\right)$, Si-O $\left(989,782\right.$, and $\left.686 \mathrm{~cm}^{-1}\right)$, AlAlOH $\left(872 \mathrm{~cm}^{-1}\right)$, and Al-O-Si deformation $\left(518 \mathrm{~cm}^{-1}\right)$ [33]; organic impurity is also detected $\left(1430 \mathrm{~cm}^{-1}\right)$. Zinc modification eliminates the organic impurity and AlAlOH while maintaining the original chemical structure of bentonite. For zinc-modified bentonite, the band broadening from 1070 to $1270 \mathrm{~cm}^{-1}$ along with the appearance of new bands at 603 and $669 \mathrm{~cm}^{-1}$ suggests the presence of bassanite [34]. Moreover, the slight increase in band intensity of $\mathrm{OH}$ stretching indicates hydrated $\mathrm{Ca}^{2+}$ and $\mathrm{Zn}^{2+}$ ions [27].

SEM micrograph (Figure 3 ) shows no evident change in surface morphology of bentonite after zinc modification. The particles have an irregular shape with sizes of less than $37 \mu \mathrm{m}$ due to 400 -mesh sieving before and after zinc modification. Sieving keeps the particle or aggregate size of bentonite small before incorporating to NR.

3.2. Antimicrobial Properties. Zinc-modified bentonite demonstrates antimicrobial properties against $M$. luteus and X. oryzae (Figure 4). The modified bentonite achieves 81.9 and $52.1 \%$ effectivity of $10 \%$ phenol against $M$. luteus and
$X$. oryzae in terms of the size of the inhibition zone (Table 2). The result shows zinc-modified bentonite to be more effective against $M$. luteus than $X$. oryzae which confirms the susceptibility of Gram-positive bacteria to zinc-induced inhibition than that of Gram-negative bacteria $[8,11]$. $\mathrm{Zn}^{2+}$ ions liberated by modified bentonite have intrinsic antimicrobial properties attributed to the depletion of antioxidant reserves, protein dysfunction, and enzyme inactivity of microbial cells [9-11].

Natural bentonite without zinc modification also shows microbial inhibition against $X$. oryzae (35.9\% effectivity of $10 \%$ phenol). Xie and Yang [35] recently reported the antimicrobial activity of $\mathrm{Ca}^{2+}$ and $\mathrm{Mg}^{2+}$ ions against cardiolipinrich Staphylococcus aureus. Both $\mathrm{Ca}^{2+}$ and $\mathrm{Mg}^{2+}$ form complexes with cardiolipin which disrupt the cell membrane and kill $S$. aureus. The higher content of cardiolipin in Xanthomonas sp. (31\% for X. campestris [36]) than that in $M$. luteus (5\% [37]) results to the selective antimicrobial effect of released $\mathrm{Ca}^{2+}$ ions from natural bentonite.

3.3. Reduction of Offensive Odor. Zinc-modified bentonite at $7.5 \mathrm{phr}$ shows the highest effect in reducing the offensive odor of masticated NR (Table 3 ). The majority ( $84 \%$ of the participants) indicated the odor intensity of raw NR filled with $7.5 \mathrm{phr}$ of zinc-modified bentonite was equal or less than to reference $2(5 \mathrm{~g} \mathrm{NR}$ per $250 \mathrm{ml})$. The remaining participants described the odor intensity to be equal or greater than reference $3(10 \mathrm{~g}$ NR per $250 \mathrm{ml})$. In terms of average odor rating, zinc-modified bentonite at $7.5 \mathrm{phr}$ improves the odor of unfilled NR by $56.8 \%$. The antimicrobial effect of $\mathrm{Zn}^{2+}$ ions released by modified bentonite lowers the microbial growth in raw NR, thereby reducing the microbial degradation of nonrubber components and the emission of offensive odor.

The results of olfactometry show improvement in the odor of NR as the proportion of zinc-modified bentonite is increased from 0 to $7.5 \mathrm{phr}$. The odor improvement drops at $10 \mathrm{phr}$ which could be due to the poor dispersion and aggregation of modified bentonite in the rubber matrix at high loading. At low filler loading, the homogenous dispersion of modified bentonite in NR allows the creation of microbial inhibition zones distributed within the rubber matrix which maximizes the antimicrobial effect of $\mathrm{Zn}^{2+}$. However, the presence of water and hydrated ions in modified bentonite makes the filler hydrophilic and incompatible with hydrophobic NR during solid mixing $[38,39]$. Filler aggregates formed from the poor dispersion limit the distribution and availability of $\mathrm{Zn}^{2+}$ within the rubber matrix.

Natural bentonite also contributes to the reduction of offensive odor, as illustrated by the steady decrease in the average odor rating of NR with the increase in the proportion of natural bentonite. The reduction in offensive odor only becomes significant at $10 \mathrm{phr}$ with odor improvement of $37.8 \%$ relative to unfilled NR and with $64.2 \%$ of participants describing the odor to be equal or less than reference 2. The obnoxious smell of NR is composed of volatile chemicals coming from different reactions: alcohols, aldehydes, carboxylic acids and hydrocarbons (from lipid 


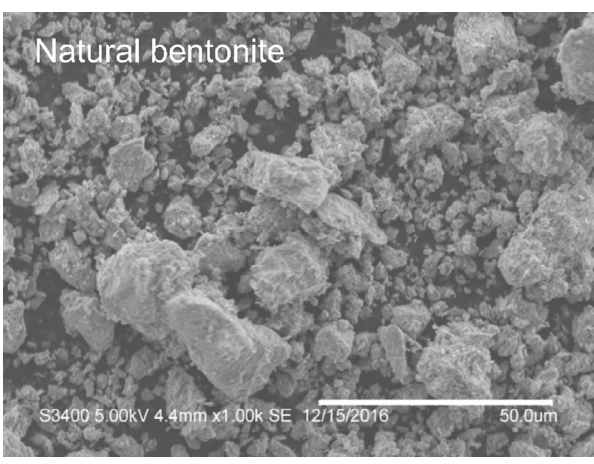

(a)

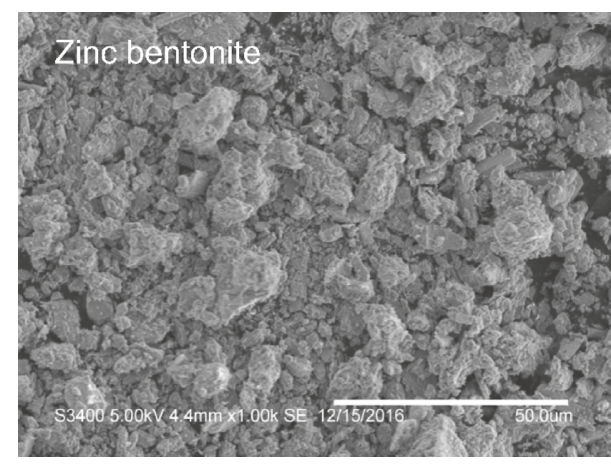

(b)

FIgURE 3: SEM micrograph of natural bentonite (a) and zinc-modified bentonite (b). Scale bar is $50 \mu \mathrm{m}$.

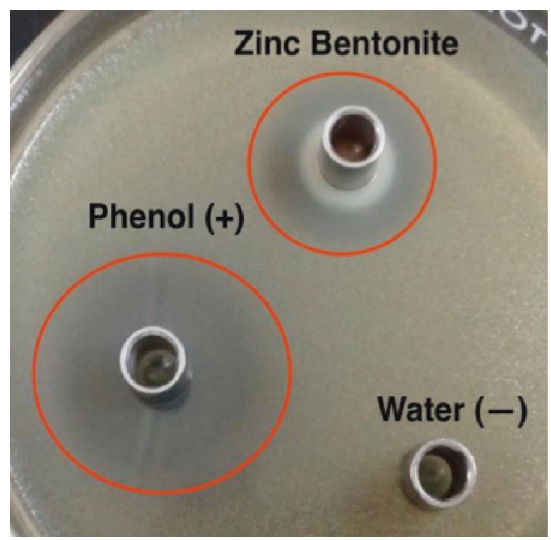

(a)

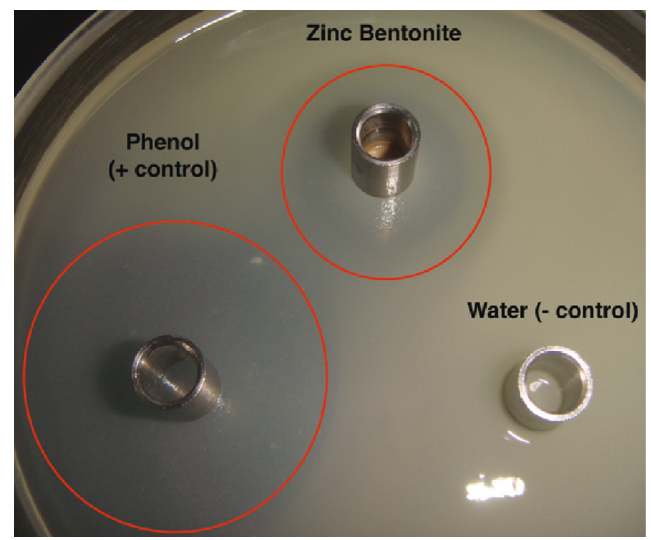

(b)

Figure 4: Antimicrobial activity of zinc-modified bentonite against M. luteus (a) and X. oryzae (b). Performance is compared with $10 \%$ phenol and distilled water as positive and negative control, respectively.

TABle 2: Mean diameter of inhibition zone of samples against $M$. luteus and $X$. oryzae.

\begin{tabular}{lcc}
\hline Sample $(\mathrm{mm})$ & M. luteus & X. oryzae \\
\hline Natural bentonite & $0.0 \pm 0.0$ & $14.0 \pm 1.2$ \\
Zinc bentonite & $21.3 \pm 1.2$ & $20.3 \pm 1.4$ \\
10\% phenol (+ control) & $26.0 \pm 1.0$ & $39.0 \pm 1.0$ \\
Distilled water ( control) & $0.0 \pm 0.0$ & $0.0 \pm 0.0$ \\
\hline
\end{tabular}

oxidation), free fatty acids (from carbohydrate fermentation), esters (from microbial esterification), and sulfurcontaining compounds (from amino acid degradation) [22]. Adsorption of these volatile components occurs in the interlayer space of clay and within the secondary pores formed by the clay particles [40]. Adsorption sites become more available as the proportion of natural bentonite increases in NR. However, the saturation of adsorption sites will eventually lead to the release of offensive smell due to the availability of microorganisms and nonrubber components.

Raw NR is more odorous than compounded and vulcanized NR. Compounding additives like zinc oxide and accelerators inhibit the microbial growth in rubber [41]; the high temperature applied to rubber during vulcanization also contributes to this effect. Therefore, much of the offensive odor of raw NR is decreased after vulcanization due to the low microbial population. Reducing the offensive odor via microbial inhibition has more effect on raw NR than vulcanized NR. Hoven et al. [1] showed that an antimicrobial agent-like benzalkonium chloride provides little improvement in the emitted odor of vulcanized NR. On the contrary, Nornanysya et al. [2] demonstrated that the soaking of raw NR in aqueous solutions of the antimicrobial agent eliminates most of the volatile compounds. Reducing the offensive odor using solid adsorbents such as carbon black, zeolite, and chitosan is more effective to vulcanized NR [1]. The treatment of bentonite with $\mathrm{Zn}^{2+}$ ions combines antimicrobial inhibition and adsorption in a single filler which can reduce the offensive odor of both raw and vulcanized NR.

3.4. Curing and Mechanical Properties. The incorporation of zinc-modified bentonite at $7.5 \mathrm{phr}$ slightly decreases the elastic torque and prolongs the scorch and cure times of NR (Table 4). Moisture carried by modified bentonite plasticizes and softens the rubber matrix which lowers the elastic torque. Moreover, the adsorption of curing agents into bentonite delays sulfur vulcanization and extends the curing of NR. Moisture-induced plasticization by zinc-modified bentonite also marginally lowers the tensile stress response of vulcanized NR (Tables 5 and 6) 
TABLE 3: Results of the olfactometry test.

\begin{tabular}{|c|c|c|c|c|c|c|c|}
\hline \multirow{2}{*}{ Filler } & \multirow{2}{*}{ Proportion (phr) } & \multicolumn{5}{|c|}{ Percentage of olfactometry test } & \multirow{2}{*}{ Mean odor rating } \\
\hline & & Reference 1 & Reference 2 & Reference 3 & Reference 4 & Reference 5 & \\
\hline None & 0.0 & 9.4 & 17.0 & 5.7 & 30.2 & 37.7 & $3.7 \pm 1.4$ \\
\hline Natural bentonite & 2.5 & 3.8 & 15.1 & 24.5 & 39.6 & 17.0 & $3.5 \pm 1.1$ \\
\hline Natural bentonite & 5.0 & 3.8 & 24.5 & 34.0 & 15.1 & 22.6 & $3.3 \pm 1.2$ \\
\hline Natural bentonite & 7.5 & 13.2 & 30.2 & 26.4 & 20.8 & 9.4 & $2.8 \pm 1.2$ \\
\hline Natural bentonite & 10.0 & 34.0 & 30.2 & 15.1 & 13.2 & 7.5 & $2.3 \pm 1.3$ \\
\hline Zinc bentonite & 2.5 & 44.0 & 32.0 & 14.0 & 6.0 & 4.0 & $1.9 \pm 1.1$ \\
\hline Zinc bentonite & 5.0 & 48.0 & 24.0 & 12.0 & 12.0 & 4.0 & $2.0 \pm 1.2$ \\
\hline Zinc bentonite & 7.5 & 62.0 & 22.0 & 12.0 & 2.0 & 2.0 & $1.6 \pm 0.9$ \\
\hline Zinc bentonite & 10.0 & 42.0 & 26.0 & 14.0 & 8.0 & 10.0 & $2.2 \pm 1.3$ \\
\hline
\end{tabular}

TABLE 4: Vulcanization parameters of unfilled NR and NR composite at $160^{\circ} \mathrm{C}$.

\begin{tabular}{|c|c|c|c|c|c|c|}
\hline Sample & $\mathrm{ML}(\mathrm{dNm})$ & $\mathrm{MH}(\mathrm{dNm})$ & ts $1(\min )$ & ts2 $(\min )$ & tc50 $(\min )$ & tc90 (min) \\
\hline Unfilled NR & 0.68 & 6.82 & 2.54 & 3.02 & 3.49 & 5.41 \\
\hline $\mathrm{NR}+7.5 \mathrm{phr}$ zinc bentonite & 0.60 & 5.45 & 3.33 & 4.11 & 4.47 & 7.57 \\
\hline
\end{tabular}

TABLe 5: Mean hardness and tensile properties of unfilled NR and NR composite before air oven ageing.

\begin{tabular}{|c|c|c|c|c|c|}
\hline \multirow{2}{*}{ Sample } & \multirow{2}{*}{ Shore A hardness } & \multicolumn{3}{|c|}{ Tensile stress at specified elongation $(\mathrm{MPa})$} & \multirow{2}{*}{ Tensile set $(\%)$} \\
\hline & & $100 \%$ & $200 \%$ & $300 \%$ & \\
\hline Unfilled NR & $30.60 \pm 0.89$ & $0.74 \pm 0.06$ & $1.13 \pm 0.11$ & $1.55 \pm 0.17$ & $1.33 \pm 1.15$ \\
\hline $\mathrm{NR}+7.5 \mathrm{phr}$ zinc bentonite & $30.40 \pm 0.55$ & $0.68 \pm 0.01$ & $1.04 \pm 0.01$ & $1.43 \pm 0.03$ & $0.67 \pm 1.15$ \\
\hline
\end{tabular}

TABLE 6: Mean hardness and tensile properties of unfilled NR and NR composite after air oven ageing.

\begin{tabular}{|c|c|c|c|c|c|}
\hline \multirow{2}{*}{ Sample } & \multirow{2}{*}{ Shore A hardness } & \multicolumn{3}{|c|}{ Tensile stress at specified elongation (MPa) } & \multirow{2}{*}{ Tensile set (\%) } \\
\hline & & $100 \%$ & $200 \%$ & $300 \%$ & \\
\hline Unfilled NR & $30.48 \pm 0.50$ & $0.79 \pm 0.03$ & $1.27 \pm 0.04$ & $1.81 \pm 0.06$ & $1.67 \pm 0.58$ \\
\hline $\mathrm{NR}+7.5 \mathrm{phr}$ zinc bentonite & $31.32 \pm 0.84$ & $0.74 \pm 0.01$ & $1.23 \pm 0.02$ & $1.78 \pm 0.04$ & $1.33 \pm 1.15$ \\
\hline
\end{tabular}

before and after air oven ageing. Meanwhile, the rigidity of bentonite allows sustenance of hardness and resistance to permanent deformation of vulcanized NR. One-way analysis of variance at $95 \%$ confidence level shows no statistically significant differences between the mean hardness (before ageing: $p=0.68$; after ageing: $p=0.07$ ), tensile stress (before ageing: $p=0.13-0.31$; after ageing: $p=0.06-0.49)$, and tensile set (before ageing: $p=0.52$; after ageing: $p=0.68$ ) of unfilled NR and NR composite. Thus, the hardness and tensile properties of vulcanized NR remain uncompromised with the use of zincmodified bentonite as a filler.

\section{Conclusions}

Modification of natural bentonite is achieved by the adsorption of $\mathrm{Zn}^{2+}$ ions on the clay surface. This modification process is also accompanied by the formation of hydrated calcium sulfate minerals such as bassanite. The controlled release of $\mathrm{Zn}^{2+}$ from zinc-modified bentonite has antimicrobial properties against $M$. luteus and X. oryzae.

The use of zinc-modified bentonite as a filler reduces the offensive odor from raw NR. The magnitude of odor reduction depends on the loading of zinc-modified bentonite in NR. At the optimum loading, zinc-modified bentonite slightly reduces the elastic torque and extends the vulcanization of NR. The mechanical properties of vulcanized NR composite remain comparable with unfilled NR. These results suggest the suitability of zinc-modified bentonite as a deodorant during mastication of raw NR.

\section{Data Availability}

The authors declare that all data supporting the findings of this study are available within the article.

\section{Conflicts of Interest}

The authors declare that there are no conflicts of interest regarding the publication of this paper.

\section{Acknowledgments}

The authors acknowledge the support provided by the following: Saile Industries Inc. for the natural bentonite; Rhodeco Processing Services Inc. and MJ Rubber 
Agricultural Products Inc. for SPR 10 and compounding ingredients; Department of Mining, Metallurgical, and Materials Engineering (University of the Philippines) for the use of laboratory mixing mill and rubber process analyzer; and Cytek Solutions Inc. for X-ray diffraction. This work was supported by the Department of Science and TechnologyNational Capital Region (DOST-NCR), Philippines.

\section{References}

[1] V. P. Hoven, K. Rattanakarun, and Y. Tanaka, "Reduction of offensive odor from natural rubber by odor-reducing substances," Journal of Applied Polymer Science, vol. 92, no. 4, pp. 2253-2260, 2004.

[2] F. K. Nornanysya, S. M. Sharifah Aminah, S. Azemi, K. Dzaraini, and W. Y. Wan Mohd Fathil, "Treatment of odor from natural rubber by using selected antimicrobial agent," in Proceedings of the 2012 IEEE Symposium on Humanities, Science and Engineering Research (SHUSER), pp. 559-564, Kuala Lumpur. Malaysia, June 2012.

[3] F. K. Nornanysya, S. M. Sharifah Aminah, and S. Azemi, "Odourless natural rubber (ONR)," Journal of Rubber Research, vol. 16, no. 1, pp. 15-35, 2013.

[4] O. H. Nautiyal, "Fragrant rubber sole with new formulation employing EVA crump," American Journal of Polymer Science, vol. 2, no. 2, pp. 14-21, 2012.

[5] N. H. Kamarulzaman, N. F. Idris, and Z. Mohd Nor, "Characteristics of odour concentration from raw rubber processing factories via olfactometry technique," Chemical Engineering Transactions, vol. 30, pp. 121-126, 2012.

[6] N. F. Idris, N. H. Kamarulzaman, and Z. Mohd Nor, "Determination of volatile fatty acids from raw natural rubber drying activity by thermal desorption-gas chromatography," Chemical Engineering Transactions, vol. 30, pp. 175-180, 2012.

[7] C. H. Perng, I. L. Cheng, I. C. Wang, and M. S. Chou, "Ozonation of odorous compounds in gases emitted from rubber processing industries," Aerosol and Air Quality Research, vol. 11, no. 1, pp. 51-58, 2011.

[8] S. Atmaca, G. Ü. L. Kadri, and R. Cicek, "The effect of zinc on microbial growth," Turkish Journal of Medical Sciences, vol. 28, no. 6, pp. 595-598, 1998.

[9] J. A. Lemire, J. J. Harrison, and R. J. Turner, “Antimicrobial activity of metals: mechanisms, molecular targets and applications," Nature Reviews Microbiology, vol. 11, no. 6, pp. 371-384, 2013.

[10] J. Pasquet, Y. Chevalier, J. Pelletier, E. Couval, D. Bouvier, and M. A. Bolzinger, "The contribution of zinc ions to the antimicrobial activity of zinc oxide," Colloids and Surfaces A: Physicochemical and Engineering Aspects, vol. 457, pp. 263274, 2014.

[11] A. Sirelkhatim, S. Mahmud, A. Seeni et al., "Review on zinc oxide nanoparticles: antibacterial activity and toxicity mechanism," Nano-Micro Letters, vol. 7, no. 3, pp. 219-242, 2015.

[12] H. H. Murray, "Current industrial applications of clays," Clay Science, vol. 12, pp. 106-112, 2006.

[13] M. Rivera-Garza, M. T. Olguin, I. Garcia-Sosa, D. Alcantara, and G. Rodriguez-Fuentes, "Silver supported on natural Mexican zeolite as an antibacterial material," Microporous and Mesoporous Materials, vol. 39, no. 3, pp. 431-444, 2000.

[14] A. Top and S. Ulku, "Silver, zinc, and copper exchange in a Na-clinoptilolite and resulting effect on antibacterial activity," Applied Clay Science, vol. 27, no. 1-2, pp. 13-19, 2004.
[15] P. Kaali, M. M. Perez-Madrigal, E. Stromberg, R. E. Aune, G. Czel, and S. Karlsson, "The influence of $\mathrm{Ag}^{+}, \mathrm{Zn}^{2+}$ and $\mathrm{Cu}^{2+}$ exchanged zeolite on antimicrobial and long term in vitro stability of medical grade polyether polyurethane," Express Polymer Letters, vol. 5, no. 12, pp. 1028-1040, 2011.

[16] K. Malachova, P. Praus, Z. Rybkova, and O. Kozak, “Antibacterial and antifungal activities of silver, copper and zinc montmorillonites," Applied Clay Science, vol. 53, no. 4, pp. 642-645, 2011.

[17] J. Hrenovic, J. Milenkovic, T. Ivankovic, and N. Rajic, "Antibacterial activity of heavy metal-loaded natural zeolite," Journal of Hazardous Materials, vol. 201-202, pp. 260-264, 2012.

[18] K. K. Krishnani, Y. Zhang, L. Xiong, Y. Yan, R. Boopathy, and A. Mulchandani, "Bactericidal and ammonia removal activity of silver ion-exchanged zeolite," Bioresource Technology, vol. 117, pp. 86-91, 2012.

[19] S. Demirci, Z. Ustaoglu, G. A. Yilmazer, F. Sahin, and N. Bac, "Antimicrobial properties of zeolite-X and zeolite-A ionexchanged with silver, copper, and zinc against a broad range of microorganisms," Applied Biochemistry and Biotechnology, vol. 172, no. 3, pp. 1652-1662, 2014.

[20] Y. Ohtake, "Degradation of vulcanised rubber productsproblems and solutions (degradation by residual chlorine in tap water, metals and ozone due to deterioration in the global environment)," Nippon Gomu Kyokaishi, vol. 79, no. 11, pp. 529-536, 2006.

[21] H. B. Bode, K. Kerkhoff, and D. Jendrossek, "Bacterial degradation of natural and synthetic rubber," Biomacromolecules, vol. 2, no. 1, pp. 295-303, 2001.

[22] J. Sakdapipanich and K. Insom, "High-resolution gas chromatography-mass spectrometry," Kautschuk und Gummi Kunststoffe, vol. 59, no. 7-8, pp. 382-387, 2006.

[23] J. Dick, Basic Rubber Testing: Selecting Methods for a Rubber Test Program, ASTM International, West Conshohocken, PA, USA, 2003.

[24] E. Olegario-Sanchez and J. C. Felizco, "Investigation of the structural properties of amorphous Philippine bentonite clay and its potential use for topical applications," Key Engineering Materials, vol. 737, pp. 401-406, 2017.

[25] Q. Shi, S. Tan, Q. Yang, Z. Jiao, Y. Ouyang, and Y. Chen, "Preparation and characterization of antibacterial $\mathrm{Zn}^{2+}$-exchanged montmorillonites," Journal of Wuhan University of Technology-Materials Science Edition, vol. 25, no. 5, pp. 725-729, 2010.

[26] O. Kozak, P. Praus, V. Machovic, and Z. Klika, “Adsorption of zinc and copper ions on natural and ethylenediamine modified montmorillonite," Ceramics-Silikaty, vol. 54, no. 1, pp. 78-84, 2010.

[27] L. Jiao, F. Lin, S. Cao et al., "Preparation, characterization, antimicrobial and cytotoxicity studies of copper/zinc-loaded montmorillonite," Journal of Animal Science and Biotechnology, vol. 8, p. 27, 2017.

[28] R. P. Singh and K. Kumari, "Calcium-zinc exchange equilibria on montmorillonite," Colloids and Surfaces, vol. 20, no. 3, pp. 239-246, 1986.

[29] J. W. Anthony, R. A. Bideaux, K. W. Bladh, and M. C. Nichols, Handbook of Mineralogy, Mineralogical Society of America, Chantilly, VA, USA, http://www.handbookofmineralogy.org/.

[30] S. A. Wilson and D. L. Bish, "Formation of gypsum and bassanite by cation exchange reactions in the absence of freeliquid $\mathrm{H}_{2} \mathrm{O}$ : implications for Mars," Journal of Geophysical Research, vol. 116, p. E9, 2011. 
[31] I. M. Kolthoff and T. Kameda, "The hydrolysis of zinc sulfate solutions, solubility product of hydrous zinc oxide and the composition of the latter precipitated from zinc sulfate solutions," Journal of the American Chemical Society, vol. 53, no. 3, pp. 832-842, 1931.

[32] G. Jozefaciuk and G. Bowanko, "Effect of acid and alkali treatments on surface areas and adsorption energies of selected minerals," Clays and Clay Minerals, vol. 50, no. 6, pp. 771-783, 2002.

[33] J. Madejova and P. Komadel, "Baseline studies of the Clay Minerals Society source clays: infrared methods," Clays and Clay Minerals, vol. 49, no. 5, pp. 410-432, 2001.

[34] Y. Liu, A. Wang, and J. J. Freemen, "Raman, MIR, and NIR spectroscopic study of calcium sulfates: gypsum, bassanite, and anhydrite," in Proceedings of the 40th Lunar and Planetary Science Conference, League City, TX, USA, March 2009.

[35] Y. Xie and L. Yang, "Calcium and magnesium ions are membrane-active against stationary-phase staphylococcus aureus with high specificity," Scientific Reports, vol. 6, article 20628, 2016.

[36] R. Moser, M. Aktas, and F. Narberhaus, "Phosphatidylcholine biosynthesis in Xanthomonas campestris via a yeast-like acylation pathway," Molecular Microbiology, vol. 91, no. 4, pp. 736-750, 2014.

[37] R. M. Epand and R. F. Epand, "Lipid domains in bacterial membranes and the action of antimicrobial agents," Biochimica et Biophysica Acta, vol. 1788, no. 1, pp. 289-294, 2009.

[38] B. B. Pajarito, W. F. F. Mangaccat, M. R. M. Tigue, and M. T. Tipton, "Moisture diffusion in natural rubber/bentonite nanocomposites: effect of clay filler treatments," Defect and Diffusion Forum, vol. 379, pp. 124-132, 2017.

[39] D. E. O. Santiago, B. B. Pajarito, W. F. F. Mangaccat, M. R. M. Tigue, and M. T. Tipton, "Effect of bentonite modification on hardness and mechanical properties of natural rubber nanocomposites," AIP Conference Proceedings, vol. 1736, no. 1, article 020047, 2016.

[40] G. Morozov, V. Breus, S. Nekludov, and I. Breus, "Sorption of volatile organic compounds and their mixtures on montmorillonite at different humidity," Colloids and Surfaces A: Physicochemical and Engineering Aspects, vol. 454, pp. 159171, 2014.

[41] Y. Li, S. Zhao, L. Zhang, Y. Wang, and W. Yu, "The effect of different $\mathrm{Fe}^{2+}$ concentrations in culture media on the recycling of ground tyre rubber by Acidithiobacillus ferrooxidans YT-1," Annals of Microbiology, vol. 63, no. 1, pp. 315-321, 2013. 


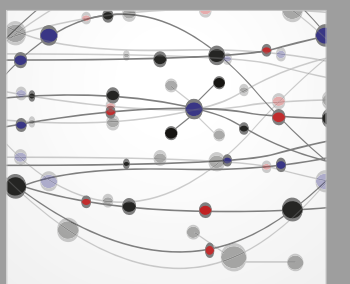

The Scientific World Journal
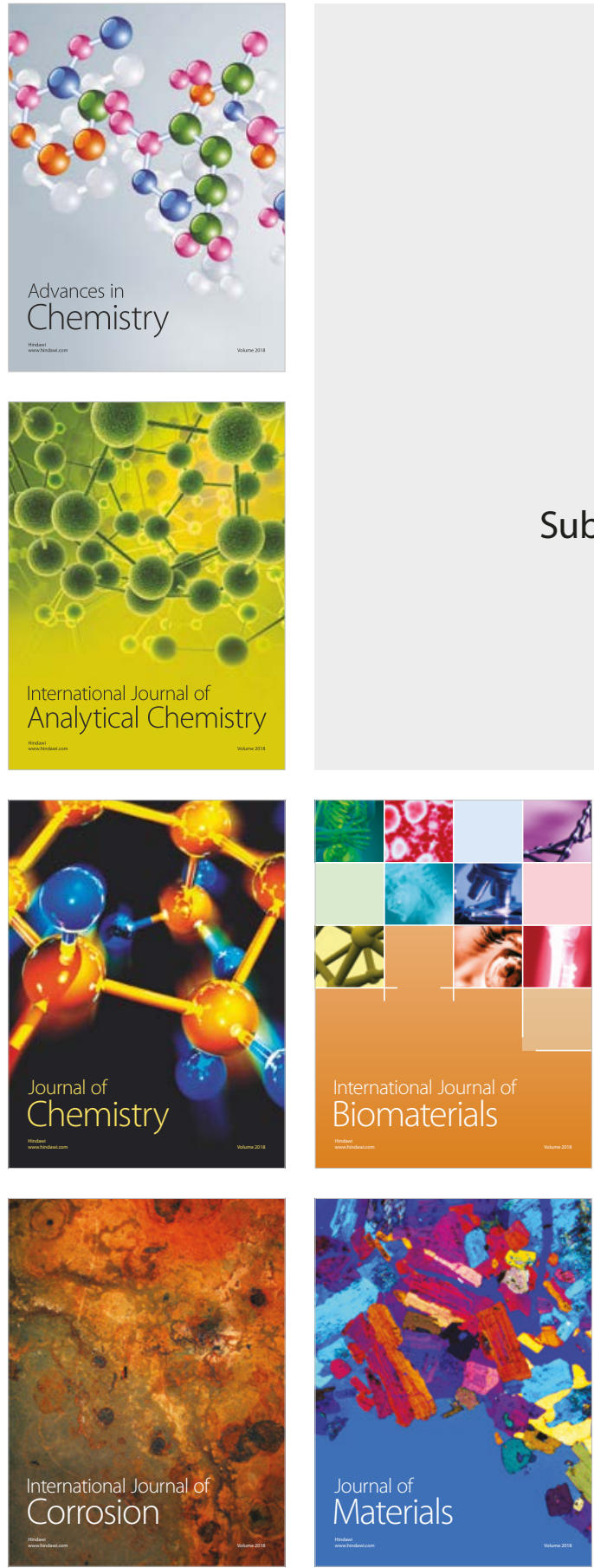

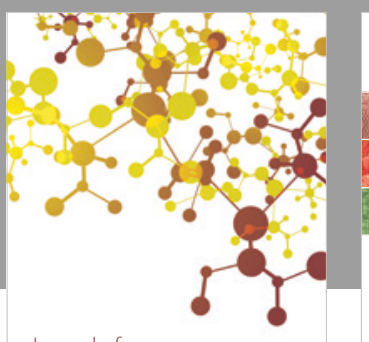

Journal of

Applied Chemistry
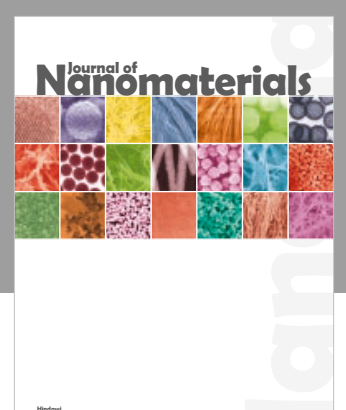

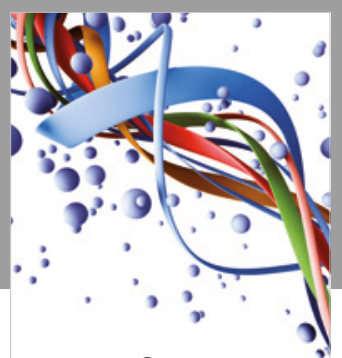

Scientifica

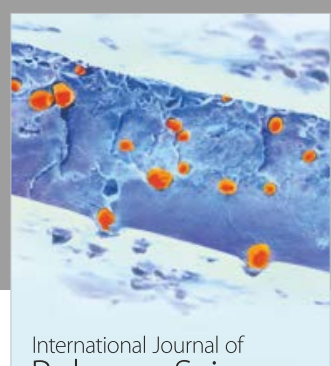

Polymer Science

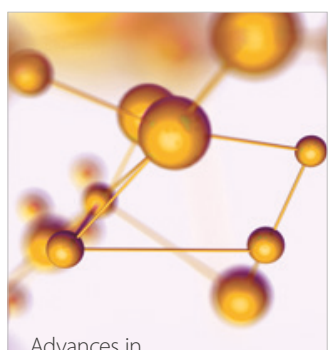

Physical Chemistry
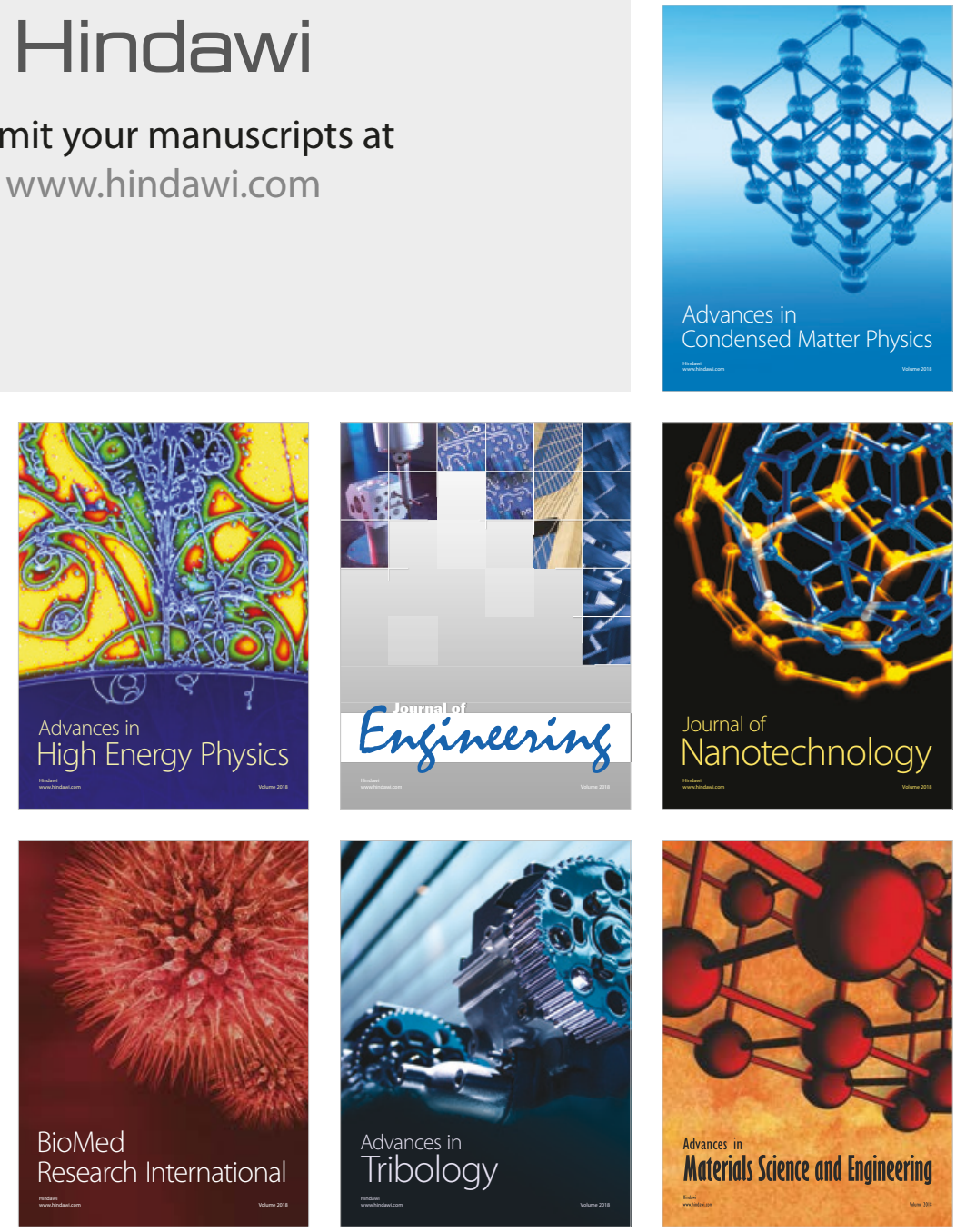